\title{
INTEROGASI W.S. RENDRA TERHADAP PEMBANGUNAN INDUSTRI ERA PEMERINTAH ORDE BARU: KAJIAN TRANSDISIPLINER
}

\author{
Umi Salamah dan Rokhyanto \\ IKIP Budi Utomo Malang \\ email: umi.salamah@budiutomomalang.ac.id
}

\begin{abstract}
(Title: Interogation W.S. Rendra on Industry Development in the Government of The New Orde Age: A Transdiciplinary Study). W.S. Rendra is a Man of letters who is always interesting to be studied from social science disciplines, because most of his works were created from the results of his research on socio politics in his era. His critical strength, his spirit of nationalism and his courage make his works to be the spirit for rising new awareness for organic intellectuals to fight against dehumanization of his nation. The New Order Government was a system of government that did not allow second choices. In the name of state stabilities, everything was commanded from the top to down. The questions were considered hostile to the state and have legal consequences. This strategy occurs in every policy. This article was taken from part of the results of research from the works of W.S. Rendra who interogated the concept and the realization of development implemented by the New Order Government. This study uses the analysis of transdisipliner theory with a designing of critical discourse proposed by Michel Foucault. The analysis of this article explains how industrial development 5.0 should be carried out for the Indonesian economic independence and the prosperity of the people.
\end{abstract}

Keywords: Interrogation, Society 5.0, New Order Government, transdisipliner studies

\section{PENDAHULUAN}

Daya kritis W.S. Rendra mulai tampak sejak Dia duduk di bangku Sekolah Dasar kelas III. Dia sudah dibiasakan oleh guru dan ayahnya untuk bersikap ilmiah, dengan cara mencari dan menghargai fakta objektif. Lake (1973) menjelaskan bahwa sejak masih bocah, pikiran-pikiran Rendra yang jenius hampir tidak dapat dimengerti oleh keluarganya. Sejak kecil, ia sudah sangat rajin membaca dan suntuk dalam menekuni bahasa Inggris. Ketika di Sekolah Dasar, W.S. Rendra sudah membaca dan menikmati karya Hemingway, John Steinbeck, William Saroyan, dan lainlain.

Sikap kritis itulah yang selalu mengusik untuk mempertanyakan konsep pembangunan yang dibuat oleh pemerintah Orde Baru. Pembangunan industri yang dinilainya sarat dengan neoimperialis, dehumanis, dan tiranis itu, menurutnya merupakan problem pembangunan yang tidak bervisi dan tidak berpihak kepada bangsa dan negara (Rendra. 1975; 1995; 2008). Bagi W.S. Rendra "Kritik" merupakan salah satu cara yang dianggapnya sebagai bentuk verifikasi data (the act of verification). Kebiasaan itulah yang mendorongnya untuk selalu membaca buku dan membaca "kehidupan", menghayati, dan bersikap kritis, terhadap fenomena kehidupan di sekitarnya (Haryono, 2000).

Sementara itu, Orde Baru memiliki sistem pemerintahan yang tidak memungkinkan munculnya pilihan kedua atau alternatif. Atas nama stabilitas, segalanya dikomando dari atas ke bawah. Pembangkangan berarti melawan negara yang memiliki konsekuensi hukum. Hal ini terjadi di setiap lini kehidupan (Aritonang, 1999). Garis komando pemerintah Orde Baru yang tegas dan berkonsekuensi hukum itu tidak hanya terdapat pada wilayah ekonomi dan politik saja, tapi juga merambah wilayahwilayah lain. Dunia kebudayaan pun tidak luput dari cengkraman pemerintah Orde Baru. Melalui aparatusnya Orde Baru mengontrol setiap aktifitas kebudayaan masyarakat dan produk budaya yang dihasilkan.

Situasi ini membuat semuanya berjalan sesuai dengan skenario Orde Baru untuk mempertahankan kekuasaannya dengan 
dalih pembangunan dan stabilitas nasional. Rezim Orde Baru menjadikan mimpi tentang pembangunan yang berkeadilan sebagai alat untuk 'memaksa' sekaligus 'merayu' masyarakat agar patuh pada setiap kebijakan yang dikeluarkan oleh pemerintah. Di samping itu, ekonomi dan politik dijalankan secara sentralistik pada satu tangan, sehingga lembaga-lembaga negara tidak berfungsi, dan cenderung menjadi boneka belaka (Aritonang, 1999:20).

Kebijaksanaan ekonomi Orde Baru yang sangat terbuka dan kapitalistik telah menyebabkan masyarakat Indonesia menjadi dunia yang sama sekali tidak sesuai dengan citacita proklamasi (Faruk, 1995:85). Pertumbuhan dan pembangunan ekonomi menjadi konsep yang diprioritaskan untuk dicapai. Hal ini membuat uang dan nilai tukar menjadi pusat aktivitas manusia. Uang menyebabkan munculnya lembaga-lembaga produksi dan konsumsi seperti pabrik-pabrik, pasar, mall, bank, dan ratusan media massa. Sepintas hal ini menjadi tanda baik untuk kesejahteraan masyarakat, namun faktanya keadaan tersebut hanya menguntungkan sekelompok kecil orang, terutama bagi mereka yang berada di lingkaran kekuasaan. Masyarakat ternyata hanya menjadi penonton pembangunan, bukan sebagai subjek pembangunan yang dilibatkan secara aktif. Dalam situasi seperti ini, yang kaya semakin kaya, yang miskin semakin miskin. Tidakpastian terjadi hampir di setiap lini kehidupan, terutama bagi masyarakat kelas bawah.

Pembangunan yang didengungkan oleh rezim Orde Baru yang seolah-olah akan membawa kesejahteraan bagi seluruh rakyat ternyata hanya retorika belaka. Krisis moral pun terjadi di mana-mana. Dipicu oleh keadaan tersebut, maka mulai muncul suara-suara sumbang yang mencoba mempertanyakan kebijakan-kebijakan rezim Orde Baru (Sarjono, 2001).

Pertanyaan-pertanyaandarimasyarakat itu ternyata ditanggapi dengan penangkapan dan penahanan oleh pemerintah Orde Baru. Setiap suara yang mencoba memberikan pandangan alternatif yang berbeda dengan pemahaman pemerintah dapat dipastikan akan berakhir di penjara, atau setidaknya interogasi penuh tekanan telah menantinya. Hal ini membuat suara-suara kritis menghilang dalam kehidupan sosial pada masa itu.

Faktanya, pada satu dekade awal Orde Baru, daya kritis masyarakat seolah-olah mengendur. Padahal pada satu dekade tersebut telah banyak penyimpangan dan ketimpangan yang terjadi di dalam masyarakat. Seperti yang digambarkan oleh W.S. Rendra pada puisinya yang berjudul 'Puisi Anak Muda' berikut ini;

\section{Kita adalah angkatan gagap \\ Yang diperanakkan oleh angkatan takabur Mahasiswa-mahasiswa ilmu ekonomi Dianggap bunga plastik, Sementara ada kebangkrutan dan banyak korupsi (Rendra, 1977)}

Pada kutipan puisi di atas dengan tegas Rendra mengatakan bahwa telah terjadi penyimpangan berupa korupsi yang mengakibatkan kebangkrutan negara. Potret realitas sosial yang terjadi pada satu dekade rezim Orde Baru yang digambarkan oleh Rendra tersebut cukup sebagai penanda bahwa rezim baru pengganti Orde Lama itu perlu untuk diluruskan melalui kritik-kritik. Namun, faktanya kritik-kritik yang diharapkan justru sepi-sepi saja. Para intelektual dan mahasiswa cenderung acuh tak acuh.

Mengendurnya kritisisme pada awal era Orde Baru itu pun juga melanda dunia kebudayaan, khususnya sastra. Ini dapat dijelaskan dengan asumsi bahwa trauma tragedi gerakan tiga puluh september oleh PKI yang baru dilewati dan kebebasan individu yang juga baru dikecap membuat sastrawan cenderung menjauh dari politik (Sarjono, 2001:168). Mereka lebih senang mendekati wilayah pribadi masing-masing dan pendalaman kemanusiaan, daripada harus berhadap-hadapan dengan represif kekuasaan yang menghasilkan rasa sakit. Terlebih lagi, sastrawan-sastrawan tersebut sebagian besar adalah pendukung lahirnya Orde Baru (manikebuis).

Dalam bukunya yang berjudul 'Sastra dalam Empat Orde Baru', Agus R Sarjono berpendapat bahwa keprihatinan politik memang kurang dimiliki oleh para sastrawan 
pada saat itu, maka tidak mengherankan jika mereka lebih tertarik untuk menggarap renik pengalaman psikologis-eksistensial manusiawi. Namun Sarjono memberikan pengecualian pada W.S. Rendra

Dalam artikel ini, pertanyaan dan sikap kritis W.S. Rendra yang dituangkan dalam karya-karya dan pidatonya disebut sebagai bentuk interogasi terhadap pembangunan oleh pemerintah Orde Baru. Interogasi W.S. Rendra terhadap ketimpangan pembangunan industri di era pemerintahan Orde baru tidak sekedar pertanyaan yang bertolak dari rasa ingin tahu tetapi pertanyaan-pertanyaan yang digali dan disertai dengan bukti, penyebab, dampak, dan solusinya terhadap keberlangsungan bangsa yang merdeka dan humanis. Pada artikel ini, interogasi dibatasi pada (1) payung hukum pembangunan yang dialankan oleh pemerintah Orde Baru dan (2) akibat dari pelaksanaan pembangunan yang dijalankan oleh Orde Baru. Pembahasan artikel yang menggunakan beberapa teori transdisipliner ini diharapkan dapat memberikan informasi yang lebih luas dan mendalam dalam penafsiran karya sastra.

\section{LANDASAN TEORI}

Teori yang digunakan untuk membedah kajian interogasi W.S. Rendra terhadap pembangunan industri oleh Pemerintah Orde Baru adalah Transdisipliner. Teori yang dimaksud, antara lain teori hegemoni Gramsci, antropologi politik falsafah Jawa, dan analisis wacana kritis Michel Faucault.

Menurut Gramsci untuk memperoleh dan mempertahankan kekuasaan, penguasa memerlukan keselarasan kekuatan ekonomi, politik, dan militer, sedangkan untuk memperoleh legitimasi kekuasaannya, penguasa melakukan hegemoni dan dominasi (Gramsci, 1986). Dua hal itulah yang digunakan untuk membahas cara Pemerintah Orde Baru melanggengkan kekuasaannya hingga 32 tahun (Chaniago, 2001; Djarot, 2006).

Berbeda dengan Gramsci yang menempatkan kekuasaan sebagai subjek yang berkuasa, Foucault menempatkan kekuasaan sebagai relasi kuasa, di mana di dalamnya ada banyak posisi yang membangun konsensus bersama. Yang menarik dari konsep Foucault adalah tesisnya mengenai hubungan antara pengetahuan dan kekuasaan. Kekuasaan selalu terartikulasikan lewat pengetahuan, dan pengetahuan selalu punya efek kuasa. Tidak ada pengetahuan tanpa kekuasaan, dan sebaliknya tidak ada kekuasaan tanpa pengetahuan (Foucault, 2002; Foucault. 2011).

Society 5.0 merupakan respon terhadap revolusi Industri 4.0 yangmenuntut konektivitas di segala hal (Internet of Thing). Society 5.0 menawarkan masyarakat yang berpusat pada manusia yang membuat seimbang antara kemajuan ekonomi dengan penyelesaian masalah sosial melalui sistemyang menghubungkan dunia maya dan dunia nyata. Shinzo Abe (2019) dalam World Economic Forum (WEF), menjelasakan dalam society 5.0 itu yang utama bukan lagi modal, tetapi data yang menghubungkan dan menggerakkan segalanya, membantu mengisi kesenjangan antara yang kaya dan yang miskin, termasuk meningkatkan layanan kedokteran dari kota hingga mencapai desa-desa kecil, serta layanan pendidikan dari tingkat dasar hingga perguruan tinggi.

Dalam kepemimpinan Jawa dikenal konsep "man is right" yang berarti tidak diperkenankan untuk sewenang-wenang dan harus bisa Ambeg Paramarta (besikap adil) serta menghayati Hasta Brata (dapat memberikan kesejukan dan ketentraman kepada warganya; membasmi kejahatan dengan tegas tanpa pandang bulu; bersifat bijaksana, sabar, ramah dan lembut; melihat, mengerti dan menghayati seluruh warganya; memberikan kesejahteraan dan bantuan bagi warganya yang memerlukan; mampu menampung segala sesuatu yang datang kepadanya, baik yang menyenangkan maupun yang tidak menyenangkan; gigih dalam mengalahkan musuh dan dapat memberikan pelita bagi warganya (Hariwijaya, 2004).

Selain itu, pemimpin dalam falsafah Jawa harus mengamalkan sikap memayu hayuning braya (berusaha menyelamatkan masyarakat), keempat, memayu hayuning bangsa (berusaha menyelamatkan bangsa), kelima yaitu memayu hayuning sasama (berusaha menyelamatkan sesama), dan keenam atau puncaknya, yaitu memayuhayu- 
ningbawana (berusaha menyelamatkan alam) (Hariwijaya, 2004)

Untuk mengkaji penelitian ini digunakan rancangan Analisis Wacana Kritis Michel Foucault. Menurut Foucault (2011), struktur wacana merupakan persepsi tentang suatu objek yang dibatasi oleh pandangan atau ideologi tertentu yang dianggap benar. Dalam proses menafsirkan struktur wacana, harus dipahami unit-unit diskursif ini membangun koherensi dan kohesivitas sebagai suatu ide/ gagasan, sehingga dapat disimpulkan sebagai "pandangan atau ideologi" tertentu.

\section{INTEROGASI TENTANG PAYUNG HUKUM PEMBANGUNAN INDUSTRI}

Interogasi W.S. Rendra terhadap pembangunan industri oleh pemerintah Orde Baru dimulai dari payung hukum yang dibuat untuk memfasilitasi dan melegalkannya. Pelaksanaan pembangunan industri di era Orde Baru sejatinya didasarkan pada pada TAP MPRS No. XXIII/1966 yang isinya bertujuan untukmemperbaiki ekonomi rakyat akibat hiper inflasi dan carut marut yang disebabkan oleh campur tangan CIA (Anderson dan Ruth, 2015, Pilger, 2002, Pilger, 2011). Perbaikan ekonomi yang dimaksud dalam Tap MPRS di atas adalah perbaikan yang mengutamakan ekonomi kerakyatan dan pemerataan, namun pemerintah Orde Baru justru berpihak pada pemilik modal raksasa dari Amerika dan sekutunya.

Untuk itu, tim ekonomi pemerintah

Orde Baru yang ditunjuk oleh Jenderal Soeharto bersama-sama dengan pemodal asing, merumuskan Undang-undang No.1 Tahun 1967 tentang Penanaman Modal Asing (UU PMA) di Swiss. Menurut Bradley R. Simpson, (2011) Sejak awal perancangannya, UUPMA 1967 telah melibatkan pihak asing, khususnya Amerika Serikat, mulai tahap merumuskan, menyusun, hingga mengkoreksi pasal-demi pasal sampai pada saat pengesahannya. Melalui payung hukum tersebut, pemerintah Orde Baru bersama dengan pemodal asing melaksanakan pembangunan industri tambang dalam bentuk kontrak karya. Dalam kontrak karya yang berpayung UUPMA no. 1 tahun 1967 tersebut, negara hanya memperoleh royalti sebesar $1 \%$ emas, dan 3,5\% tembaga, dengan luas area tambang 2,6 juta ha. Payung hukum yang tidak berkedaulatan tersebut dipertanyakan olehW.S. Rendra pidato kebudayaan di ITB tahun 1975 dan di Mahkamah Konstitusi (MK) tahun 2009, sebagai berikut:

"Industrialisasi dilakukan dengan mendatangkan modal asing yang bebas pajak, alat berproduksi juga didatangkan dari luar negeri dengan bebas pajak, dan bahan baku juga diimport dengan bebas pajak pula, kemudian pabrik yang didirikan juga bebas dari pajak berikut tanahnya. Yang kena pajak cuma keuntungannya. Itupun boleh ditransfer keluar negeri. Jadi devisa terbuka! Alangkah total dan rapi pemerintah Hindia Belanda membangun "Mesin Budaya" penghisapan terhadap daya hidup rakyat dan kekayaan alam lingkungan Indonesia. Semuanya itu dikokohkan dengan "Ordonansi Pajak 1925". Selanjutnya setelah merdeka, Orde Baru mengubah namanya menjadi UUPMA (Undang-undang Penanaman Modal Asing 1967 dan Tax holiday 1970. Lalu sekarang, ya hal ini tentu saja akan dipelihara oleh kekuatan-kekuatan kapitalisme liberal yang pada dasarnya inti penjajahan yang menguasai kita. Dan selagi kita belum mempunyai kemampuan menghasilkan mesin-mesin berat dan tenaga-tenaga manusia tingkat spesialis yang cukup jumlahnya, pemerintah kita, sejak zaman Orde Baru, telah menjual modal alam" (Rendra, 2009)

Isi teks pidato tersebut sebelumnya telah disampaikan oleh W.S. Rendra dalam bentuk puisi tahun 1967, berjudul "Kesaksian tahun 1967" dengan sebagai berikut:

Dunia yang akan kita bina adalah dunia bajakaca dan tambang-tambang yang menderu.

Bumi bakal tidak lagi perawan, tergarap dan terbuka. sebagai lonte yang merdeka. Mimpi yang kita kejar, mimpi platina berkilatan.

Dunia yang kita injak, dunia kemelaratan. ... (Rendra, 1971) 
Melalui puisi di atas,W.S. Rendra menginterogasi pembuatan payung hukum tersebut dengan menjelaskan prediksi dari pembangunan industri tambang yang berpayung UUPMA tahun 1967, bahwa pembangunan industri yang dilakukan oleh modal dan teknologi raksasa dari asing dalam bentuk kontrak karya akan mengakibatkan kekayaan dan kecantikan bumi pertiwi dijamah dan dihisap oleh kapitalis asing dengan harga yang sangat murah, seperti "lonte yang merdeka", alam dan tata lingkungan rusak, seperti "Bumi bakal tidak perawan", kekayaan yang yang berlimpah diambil pemilik modal bukan untuk rakyat, seperti mengejar mimpi platina berkilatan, dan rakyat terpinggirkan dan termiskinkan, ibarat "Dunia yang kita inak kemelaratan". Dengan begitu, harmonisasi antara alam dan manusia akan rusak.

Dengan berlindung pada UUPMA nomor 1 tahun 1967, siapapun kapitalis asing, bisa menghisap dan menikmati hasil kekayaan bumi pertiwi di negeri ini dengan mudah dan murah, asal punya "Duit" dan berkomplot dengan penguasa Orde Baru. Apa yang dilakukan oleh elit pemerintah Orde Baru (Orba), mirip dengan yang terjadi ketika Hindia Belanda mempengaruhi Amangkurat 1 dan Amangkurat II(Rendra, 1997).

Selain menggunakan UUPMA 1967, untuk melancarkan pembangunan industri yang tidak berdaulat, Pemerintah Orde Baru merumuskan struktur diskursus pembangunan berupa "Trilogi Pembangunan" dan stabilitas pembangunan, serta PKI musuh bersama. Diskursus tersebut sengaja diciptakan untuk memperoleh legitimasi pelaksanaan pembangunan ekonomi makro di Indonesia dan mengancam siapa saa yang berusaha menghalanginya. Berdasarkan diskursus tersebut dibuat regulasi-regulasi untuk menghalalkan tindakan pemerintah atas nama pembangunan dan stabilitas nasional.

Diskursus yang merupakan turunan dari wacana developmentalisme tersebut seakan-akan menjadi alernatif perbaikan ekonomi sebagai sarana untuk memperkuat perekonomian negara, terutama melalui proses industrialisasi dengan penanaman modal asing dan hutang luar negeri (Fakih 2001). Konsep pembangunan makro yang didasarkan pada ideologi kapitalisme tersebut, diterima apa adanya oleh elit penguasa Orde Baru, seakanakan sebagai 'solusi' terhadap kemerosotan ekonomi Indonesia pasca kolonial, yang membawa arah perbaikan dari yang tradisional ke yang modern dan dari yang terbelakang ke arah yang lebih maju (Smith, 1985).

Selain itu, pembangunan yang dijalankan oleh Orde Baru berada pada arahan dan kontrol sebagai syarat-syarat hutang luar negeri dan penanaman modal asing dari IMF dan World Bank. Pembangunan ekonomi makro diutamakan dan pembangunan ekonomi mikro diabaikan. Konsep pembangunan ekonomi makro yang didasarkan pada ideologi developmentalisme kapitalisme memiliki tujuan terselubung dari negara maju untuk mempertahankan dominasi kekuasaan terhadap negara-negara berkembang. Dengan begitu, arah pembangunan ekonomi makro dengan penanaman modal asing dan hutang luar negeri sejatinya menjadi alat hegemoni kekuasaan kapitalis yang dianggap paling tepat pada saat itu, setelah bentuk kolonialisme dan imperialisme sudah tidak relevan lagi dengan perkembangan zaman pasca perang dunia II. Dalam hal ini W.S. Rendra mempertanyakan payung hukum tersebut dengan mengatakan sebagai berikut:

Anehnya, pemerintah Orba malah mengejar pembangunan khayalan yang bertumpu pada modal asing dan ekonomi makro semata. Modal asing yang masuk pun tidak pernah mau menjamah pembangunan infrastruktur ekonomi untuk perdagangan antardaerah dan antardesa. Modal asing rata-rata hanya menggarap potensi bangsa kita sebagai pasar.

"Trilogi Pembangunan" yang drancang tanpa arah, tanpa tata buku masa lalu dan tata buku masa kini, seperti "Tembang", yang hanya indah untuk didengarkan, namun pelaksanaannya menyengsarakan rakyat yang oleh W.S. Rendra disebut sebagai daya mati (Rendra, 1997).

Pembangunan yang yang dilaksanakan oleh Orde Baru benar-benar pembangunan yang hanya membangun kesejahteraan penguasa bukan kesejahteraan rakyat. Dalam hal ini 
W.S. Rendra mengatakan dalam interogasinya sebagai berikut:

Ketatanegaraan kita yang sableng juga menyebabkan pemerintah kita dari sejak Orde Baru dan Orde Reformasi melengahkan pembangunan perdagangan dalam negeri yang berlandaskan usaha kecil menengah. Bahwa pemerintah kolonial Hindia Belanda tidak mengindahkan kemajuan perdagangan dalam negeri, tidak pula mengembangkan kemampuan yang dahsyat dari usaha kecil menengah! (Rendra, 2008)

Ketergantungan pada modal dan pinjaman luar negeri menyebabkan pemerintah Orba tersesat dalam politik perdagangan lembaga-lembaga asing dan perusahaan multi nasional (Rendra 2008; Chaniago, 2001). Pembangunan yang dilaksanakan oleh pemerintah Orde Baru sarat dengan kepentingan ekonomi-politik elit penguasa, yaitu penumpukan pundi-pundi ekonomi sebagai basis struktur untuk melanggengkan kekuasaan. Dalam hal ini, W.S. Rendra dalam interogasinya mengatakan bahwa:

Lebih jauh lagi Orde Baru lebih percaya pada kemampuan berhutang pada lembaga Donor Asing daripada membangun kekuatan madal dalam negeri. Sudah jelas merupakan kesalahan besar membangun ekonomimakrotanpamembangun ekonomi mikro. Teori "tricle-down effect" itu tipu daya belaka. Nyatanya alam menjadi rusak. Hutang ber-milyard-milyard dollar yang semua harus ditanggung oleh rakyat (Disampaikan dalam Pidato Kebudayaan Penerimaan Gelar HonorisCausa (2008) dan dalam diskusi kebudayaan di ITB (1975) UI, 1979, Atmajaya (1985), UGM (1995)..

Kutipan di atas menunjukkan bahwa prioritas pembangunan ekonomi makro dengan hutang luar negeri berdasarkan teori "Tricledown effect" merupakan tipu daya belaka. Faktanya, hasil-hasil pembangunan hanya dinikmati oleh pemilik modal dan para elit kekuasaan.
Selain itu, pembangunan industri pariwisata uga dilaksanakan atas permintaan dan kontrol IMF dan Bank dunia. Untuk memayungi program pembangunan industri pariwisata di Bali, dibuatlah Undang-Undang yang melegalkan pembangunan industri pariwisata oleh para pemilik modal, seperti tertuang dalam Undang-undang Nomor 3 Tahun 1970 Bab V, pasal 13 huruf e.

Berdasarkan analisis di atas, payung hukum pembangunan industri yang dibuat oleh pemerintah Orde Baru berupa UUPMA 1967 sangat berbahaya bagi kedaulatan dan kemandirian bangsa. Hal itu disebabkan oleh strategi pembangunan yang tidak sesuai dengan potensi sumberdaya manusia yang ada, tidak memanusiakan rakyat, tidak menjaga kelestarian budaya, tidak menaga lingkungan, dan tidak berkeadilan sosial bagi seluruh rakyat Indonesia. Diskursus-diskursus yang dirumuskan dalam Trilogi Pembangunan, StabilitasNasional, danPembangunanEkonomi Makro, hanya indah dalam wacana namun sangat berbahayaa dalam implementasinya. Sebagai orang yang sama-sama dibesarkan dalam falsafah hidup orang Jawa, payung hukum tersebut bertentangan dengan prinsip mamayuhayuning bangsadanbudaya, dan bawana. Apabila strategi pembangunan Orde Baru dilanjutkan saat ini, maka society 5.0 mustahil dapat diimplementasikan di Indonesia, karena budaya manipulasi data sudah mengakar kuat, sementara akar dari sociaty 5.7 adalah data yang akurat.

\section{INTEROGASI TERHADAP AKIBAT PEMBANGUNAN OLEH ODE BARU}

Sejak diterbitkannya UU PMA No. 1 Tahun 1967 itu, dalam jangka waktu tiga tahun (1967-1970) terdapat sembilan perusahaan raksasa dunia yang berhasil mengantongi izin operasi pertambangan dari pemerintah Orde Baru dalam bentuk kontrak karya. Sembilan perusahaan tersebut, di antaranya PT Freeport McMoran, minyak Exxon Mobil, Chevron, Texaco, Caltex, dan Stanvac. PT Freeport merupakan perusahaan asing pertama yang berinvestasi di Indonesia dalam bentuk kontrak karya (Anderson dan Ruth, 2015, 2009; 
Chaniago, 2001, Kwik, 2011). Freeport Sulphur adalah perusahaan asing pertama yang masuk dan beroperasi di Indonesia dengan dasar UU PMA No. 1 Tahun 1967 dalam bentuk kontrak karya. Dalam perjanjian tersebut, negara sangat dirugikan karena hanya memperoleh royalti yang sangat kecil, yakni 1\% emas dan $3 \%$ tembaga (Simpson, R. Bradley 2011).

W.S. Rendra mempertanyakan "Mengapa pemerintah Orde Baru mengizinkan pembangunan industri tambang kepada kapitalis asing, padahal Indonesia sebagai pemilik kekayaan belum memiliki saranasarana pendukung yang mampu untuk menggarap industri tersebut. Menurut W.S. Rendra, seharusnya pemerintah Orde Baru menyiapkan sarana-sarana pendukung pembangunan industri terlebih dahulu dari hulu ke hilir, sebelum mengambil keputusan untuk membangun industri berupa tambang (Rendra, 1975; 1995; 2009). Akibatnya, pembangunan industri tambang itu telah menyisakan masalah berupa kerusakan lingkungan, kehilangan sumber pendapatan negara, kerusakan moral kemanusiaan, ketidakadilan, dan tumbuhkembangnya mentalitas korupsi di kalangan pejabat. Pembangunan industri tambang oleh kapitalis asing di era Orde Baru pemerintah Orde Baru, menurut W.S. Rendra merupakan daya mati yang menghisap daya hidup rakyat. Itulah sebabnya, W.S. Rendra mempertanyakan dengan menunjukkan fakta dan akibatnyayang disampaikan dalam pidato penganugerahan Gelar Doktor Honoris Causa di UGM sebagai berikut:

Akibat dari tidak adanya industri hulu, industri kita di hampir semua bidang: pesawat terbang, mobil, sepeda, obat batuk hitam, obat flu, cabe, kobis, padi, jagung, ayam potong, dll, dll, dll, semua assembling! Alat berproduksi dan bahan bakunya diimport!

... Akibatnya yang memperoleh keuntungan besar adalah modal asing yang memiliki teknologi berat dan tenagatenaga spesialis. Alam dan lingkungan rusak karena kita memang tak berdaya menghadapi kedahsyatan kekuatan modal asing (Rendra; 2004).
Pembangunan industri dan ekonomi makro dengan hutang luar negeri dan penanaman modal asing, memiliki maksud yang tersubung, baik dari negara donor maupun para elit kekuasaan. Bagi elit dimaksudkan untuk penumpukan pundi-pundi ekonomi, karena dengan cara tersebut, Presiden Soeharto, tim, dan kroninya mendapatkan gratifikasi sebanyak $10 \%$ dalam setiap transaksi. Jumlah tersebut 10 kali dari royalti yang diberikan oleh perusahaan asing kepada negara (Djarot, 2006). Dengan demikian wajar, jika para mantan elit, tim, dan kroninya menjadi sangat kaya raya hingga saat ini. Budaya gratifikasi $10 \%$ tersebut disampaikan dalam bentuk pasemondan kelakar oleh W.S Rendra dalam Lakon Perjuangan Suku Naga sebagai berikut:

Pada waktu itu, duta besar dari negaranegara sahabat pada berkumpul. Kepada mereka ditanyakan kesanggupan negaranegara yang mereka wakili akan memberi pinjaman kepada negara Astinam Puram. Setiap duta menyuarakan kesanggupannya. .... Tiba-tiba Duta V berkata "70 milyar dolar dan 10\% komisi (Rendra, 1975: Perjuangan Suku Naga, hal. 14)

Bagi yang memahami konteks saat itu, pada saat membaca/mendengar $10 \%$ pasti memahami makna $10 \%$ sebagai gratifikasi/ komisi. Kata "Tien" Soeharto mengasosiasikan wajib gratifikasi $10 \%$ pada setiap pemberian izin operasional modal-modal asing dan pinjaman luar negeri di Indonesia (Sumanto, 2003).Dari sinilah sejatinya budaya gratifikasi $10 \%$ yang saat ini menjerat para Kepala Daerah dan DPR tertangkap operasi tangkap tangan (OTT) oleh Komite Pemberantasan Korupsi (KPK).

Penggunaan wacana Stabilitas Nasional sebagai kedok untuk melindungi pemodal asing dan elit kekuasaan Orde Baru tersebut, oleh W.S. Rendra juga dibeberkan dalam interogasinya secara berkelakar dalam Lakon Perjuangan Suku Naga. Dijelaskan pada folder leaflet lakon/drama Perjuangan Suku Naga menjelaskan kepada pembaca bahwa drama ini diangkat dari kenyataan berdasarkan hasil wawancara terhadap berbagai lapisann dan elemen masyarakat, meskipun nama-nama 
yang ditampilkan tidak ber-setting Indonesia. Sinopsisnya sebagai berikut:

Kisah ini diawali dengan sebuah negeri yang bernama Astinam Puram. Di negeri itu ada sebuah desa bernama Desa Suku Naga. Kepala desanya bernama Abivasam. Ia mempunyai seorang putra yang sedang sekolah di luar negeri, bernama Abivara. Setelah tamat, Abivara yang lebih senang tinggal di desa, pulang bersama teman, wartawan berkulit putih bernama Carlos.

Pada saat yang hampir bersamaan, pemerintah Astinam Puram kedatangan seorang tamu, bernama Mr. Joe dkk. Ia salah seorang pembantu pemilik modal sangat kaya raya namanya The Big Bos. Tamu itu ingin membangun tambang tembaga yang ada di Desa Suku Naga. Para tamu itu menginginkan Desa Suku Naga dijadikan kota pertambangan tembaga. Untuk itu, orang-orang yang tinggal di desa harus dipindahkan dengan cara besarbesaran ("Bedhol Desa").

Tentu saja para penduduk di Desa Suku Naga menolak. Alasan mereka, dengan membangun kota pertambangan di desa itu, dan memindahkan mereka ke tempat lain sama artinya dengan merusak tradisi yang sudah mereka bangun berabad-abat lamanya.

Akan tetapi, pemerintah Astinam Puram sangat gigih melancarkan usahanya dengan berbagai pendekatan. Salah satunya adalah mengutus Menteri Pertambangan yang kemudian disusul oleh Ketua Parlemen untuk melakukan persuasi/pembujukan kepada rakyat. Sementara itu, pemerintah Astinam Puram juga membuat wacana subversi yang berisi ancaman bahwa mereka yang menolak dipindahkan dan ingin mempertahankan desa itu akan disebut sebagai pembangkang atau mbalelo, Sebagai ganjarannya digebuk (diintimidasi, disiksa, bahkan dibunuh).

Usaha Menteri Pertambangan dan Ketua Parlemen dengan cara persuasif sia-sia. Akan tetapi mereka membawa pasukan tentara untuk menakut-nakuti penduduk setempat. Meskipun demikian, penduduk desa Suku Naga bertahan mati-matian.

Bagi Carlos, wartawan dari manca negara itu, adalah suatu bahan pemberitaan yang menarik. Carlos melihat kejanggalan, karena tidak ada satu pun pers di Astinam Puram yang memberitakan peristiwa itu. Sebaliknya, bagi Negeri Astinam Puram, hal itu wajar, karena insan-insan pers sudah ditatar dan sudah diarahkan oleh Pak Menteri Penerangan agar memiliki self sensorship, yaitu kesadaran menyensor diri sendiri untuk tidak memberitakan hal-hal yang bersifat memusuhi pemerintah dan yang bisa ditafsirkan sebagai penghambat pembangunan.

Carlos pun segera dicurigai, sebab selama tinggal di Desa Suku Naga, ia telah memberikan bahan-bahan pemberitaan untuk korannya yang terbit di luar negeri. Itulah yang menyebabkan izin tinggalnya dicabut dan harus pulang ke negerinya. Lakon ini diakhiri dengan perpisahan penduduk Desa Suku Naga dengan Carlos.

Lakonyang dengan sengaja disamarkan setting dan nama pelakunya tersebut, membeberkan fakta sosial di era kekuasaan pemerintah Orde Baru. Keberpihakan elit pemerintah Orde Baru terhadap kepentingan industri pertambangan Freeport. Pemerintah Orde Baru juga menjamin keamanan dan kenyamanan investor di Papua dengan menempatkan para jendral sebagai direkturnya. Pengamanan dilakukan dengan cara-cara penekanan, pengusiran, dan pemberangusan kebudayaan/tradisi rakyat yang telah dibangun berabad-abad. Hak masyarakat pun terampas, rakyat ditakut-takuti, diintimidasi, sehingga mengakibatkan ketakutan dan trauma yang mendalam (Rendra, 1995; Chaniago. 2001). Kondisi tersebut membuat kehidupan rakyat makin miskin dan sengsara. Inilah yang disebut oleh W.S. Rendra sebagai daya mati. Akibat dari pembangunan Makro, disampaikan oeleh W.S. Rendra sebagai berikut:

Para elite politik lupa bahwa sejak abad 18 perdagangan antar pulau dan antar desa sudah berkembang dengan jayanya di Nusantara. Bahkan perdagangan itulah yang menjadi tali persatuan Nusantara, bukan serdadu atau pemusatan kekuasaan. Perdagangan itu yang mendorong rasa berbangsa dan menjelmakan bahasa persatuan dengan huruf yang sama 
dan kalender sama. Bahkan mampu mendorong tatanan hidup bermasyarakat yang multikultur di kota-kota pelabuhan dan kota-kota besar di pedalaman.

Tentu saja para penjajah tidak alpa menindas kehidupan perdagangan antardaerah, antarsuku, antardesa, demi kepentingan hak monopoli perdagangan mereka. Tetapi setelah kita merdeka, seharusnya kita tidak terlambat untuk memulihkan daulat perdagangan rakyat antar daerah, antar pulau, dan antar desa (Rendra, 1975; 1995; 2008).

Akibat pembangunan yang mengutamakan ekonomi makro dengan perdagangan bebas dan mengabaikan potensi dan kepentingan sebagian besar rakyat, masa depan bangsa menjadi makin tidak jelas, ketimpangan ekonomi dan ketidakadilan sosial makin besar. W.S. Rendra menyebutnya sebagai darurat ketidakadilan sosial, sebagaimana disampaikan dalam puisi "Kesaksian Akhir Abad" sebagai berikut:

Dengan puisi ini aku bersaksi

Bahwa sampai puisi ini kutandatangani rakyat belum merdeka

Bagaiman rakyat bisa merdeka

bila pemerintah melecehkan perdagangan antardaerah

dan mengembangkan merkantilisme

Daendels

sehingga rela menekan kesejahteraan

buruh, petani, nelayan, guru

dan serdadu berpangkat rendah?

(Rendra, 1999)

Kutipan di atas menunjukkan bahwa, pembangunan yang dilaksanakan oleh pemerintah Orde Baru hanya mengutamakan pembangunan sarana-sarana industri dan perdagangan pemilik modal asing dengan mengabaikan pembangunan sarana-sarana ekonomi dan perdagangan rakyat kecil dan menengah. Padahal sejarah telah membuktikan bahwa tulang punggung ekonomi yang tangguh dan tahan terhadap krisis adalah perdagangan rakyat kecil dan menengah Rendra, 2004). Hal itu dipertegas oleh W.S. Rendra dalam pidato kebudayaannya sebagai berikut:
Pembangunan dalam negara kita juga melupakan sarana-sarana pembangunan rakyat kecil dan menengah. Padahal mereka adalah tulang punggung yang tangguh dari kekuatan ekonomi bangsa. Jumlahnya mencapai 45 juta dan bisa menampung 70 juta tenaga kerja. Sedangkan sumbangannya pada Gross National Product adalah 62\%. Lebih banyak dari sumbangan BUMN. Namun begitu program pemerintah tidak dengan positif membantu usaha mereka: Jalanjalan darat yang menjadi penghubung antar desa, yang penting untuk kegiatan ekonomi, rusak dan tak terurus. Bahan baku selalu terbatas persediaannya. Banyak bank yang tidak ramah kepada mereka. Grosir-grosir mempermainkan dengan check yang berlaku mundur. Dan pemerintah tidak pintar melindungi kepentingan mereka dari permainan kartel-kartel yang menguasai bahan baku (Rendra, 1995).

Konsep pembangunan ekonomi makro yang dijalankan oleh pemerintahan Orde Baru dengan wacana stabilitas nasional menyebabkan makin maraknya konspirasi antara elit pemerintah dengan pemodal asing (Wood, 2013). Ternyata di balik penanaman modal asing dan hutang luar negeri, terdapat maksud yang tidak etik, yakni adanya gratifikasi untuk penumpukan pundi-pundi ekonomi keluarga dan kroninya sebagai jaminan untuk melanggengkan kekuasaan. Interogasi terhadap konspirasi para elit tersebut oleh W.S. Rendra disampaikan dalam Lakon Perjuangan Suku Naga sebagai berikut:

. ... "Permohonan mereka harus diberi perhatian yang utama asal ada pengertian (hal 18). Apa yang dimaksud dengan pengertian itu? Perdana menteri menjelaskan bahwa pengertian mereka cukup besar. Lalu, dengan penuh hormat, ia mengatakan, "Mereka akan menyediakan $10 \%$ dari modal untuk halhal yang tidak diduga, yang pemakaiannya terserah Sri Ratu dan langsung akan dimasukkan ke dalam rekening Sri Ratu di Bank Hongkong". Mendengar pernyataan Perdana Menteri yang demikian itu, Sri Ratu langsung memberikan reaksi positif, “itu bagus". (Rendra, 1975). 
Dalam kutipan lakon di atas, W.S. Rendra menunjukkan fakta sosial dengan metafor bahwa "Sri Ratu" sebagai simbol Ibu negara pada waktu itu menyetujui semua izin usaha atau pun hutang luar negeri oleh swasta apabila ada gratifikasi $10 \%$ yang langsung ditransfer ke dalam tabungannya diluar negeri.

Kebijakan pembangunan ekonomi makro dinilai oleh W.S. Rendra sama dengan pola-pola pembangunan penjajah tempo dulu. Pembangunan jalan-jalan untuk melancarkan perdagangan para cukong dan pengambilan bahanmentah,makayang dibangunadalahjalanjalan tol di kota besar, bukan jalan di pedesaan atau pesisir yang menjadi sarana pergerakan perekonomian rakyat. Jadi, pemberian hutang dan bantuan luar negeri tersebut sebenarnya merupakan cara yang cerdik dan licik oleh asingsebagai pengganti dari rantai dan cambuk seorang mandor terhadap budak di zaman penjajahan (Toussaint, 2015). Rakyat dipaksa sebagai budak dan pemakai produk-produk negara industri tanpa diberi kesempatan untuk memproduksi sesuai dengan kebutuhan sendiri. Akibat hasil pembangunan ekonomi makro yang terpusat di kota metropolitan disampaikan oleh W.S. Rendra dalam "Sajak Tahun Baru" sebagai berikut:

\footnotetext{
Kota metropolitan di dunia ketiga adalah nadi dari jantung negara maju.

Nadi yang akan mengidap kanker yang akan membunuh daya hidup desadesa dan akhirnya, tanpa bisa dikuasai lagi menjadi jahat, hina dan berbahaya. Itulah penumpukan yang tanpa peredaran. (Rendra, 1990)
}

Dalam kutipan puisi di atas, W.S. Rendra menyampaikan interogasinya dengan memperlihatkan akibat dari pembangunan kota-kota metropolitan yang dibangun dari hutang luar negeri hanya merupakan sarana dan prasarana vital bagi negara-negara industri maju untuk "merampok dan menumpuk" kekayaan dari Indonesia. Pembangunan seperti itu, sangat berbahaya bagi kedaulatan bangsa dan negara.
Pembangunan ekonomi makro yang hanya terpusat di kota metropolitan menyebabkan perputaran perekonomian hanya di kota-kota besar saja, sehingga perekonomian di desa-desa menjadi macet. Perkembangan perekonomian desa menjadi lambat sehingga masyarakat desa menjadi tertarik untuk mencari penghidupan yang lebih baik dengan cara berpindah ke kota-kota besar. Dengan bekal pengetahuan dan keterampilan seadanya, mereka bekerja menjadi pembantu rumah tangga, pengamen, pengemis, bahkan tidak sedikit yang menjadi preman (Chaniago, 2001), Fakta ini sudah menggugurkan salah satu struktur dalam wacana "Trilogi Pembangunan", yakni pembangunan yang merata. Kesenjangan antara kehidupan di desa dan kehidupan para elit beserta kroninya di kota, digambarkan oleh W.S. Rendra melalui "Sajak Sebotol Bir" sebagai berikut:

\author{
Hiburan kota besar dalam semalam, \\ sama dengan biaya pembangunan sepuluh \\ desa!... \\ Mengapa kita membangun kota \\ metropolitan? \\ dan alpa terhadap peradaban di desa? \\ Kenapa pembangunan menjurus kepada \\ penumpukan, \\ dan tidak kepada pengedaran? \\ Dimanakah jalan lalu lintas yang dulu? \\ Yang menghubungkan desa-desa dengan \\ desa-desa? \\ Kini telah terlantarkan. \\ Menjadi selokan atau kubangan. \\ Jalan lalu lintas masa kini, mewarisi pola \\ rencana penjajah tempo dulu, adalah alat \\ penyaluran barang-barang asing dari \\ pelabuhan ke kabupaten-kabupaten dan \\ bahan alam dari kabupaten-kabupaten ke \\ pelabuhan. \\ Jalan lalu lintas yang diciptakan khusus, \\ tidak untuk petani, tetapi untuk pedagang \\ perantara dan cukong-cukong. \\ Kenapa lingkungan kita sendiri tidak \\ dikira? (Rendra, 1971)
}

Dalam kutipan di atas, W.S. Rendra mempertanyakan, mengapa pembangunan dilaksanakan tetapi kesenjangan perputaran ekonomi di desa dan di kota makin lebar, yang digambarkan dengan "Biaya hiburan di kota 
satu malam setara dengan biaya pembangunan 10 desa". Hal tersebut menggambarkan kenyataan yang sangat kontras antara rakyat di desa dan para elit di kota-kota besar sebagai cerminan peradaban 'pincang' yang dibangun oleh kekuasaan Orde Baru. Pembangunan desa dan pesisir 'dianggap' tidak menguntungkan secara ekonomi bagi penumpukan kekayaan penguasa dan pemodal asing, sengaja diabaikan. Sumber daya alam/ kekayaan alam di desa dikuras dibawa ke kota untuk kemakmuran penguasa Orde Baru, kroni, dan pemodal asing. Sementara, masyarakat desa yang hidupnya serba kekurangan tergiur untuk mengadu nasib dengan urbanisasi ke kota dengan bekal seadanya. Dengan sinis, Rendra menyebut pembangunan yang dijalankan oleh Orde Baru, sebagai kecoa pembangunan dan tahayul pembangunan yang diungkapkan dalam puisi Kecoa pembangunan sebagai berikut:

Keamanan, ketenangan katanya...

Marsinah terbunuh, petani di gusur,

kenyataannya....

Kecoa Pembangunan,

Kecoa bangsa dan negara

Lebih berbahaya ketimbang raja singa

Lebih berbahaya ketimbang pelacuran

Kabut gelap masa depan,

Kemarau panjang bagi harapan

Kecoa...kecoa... ke...co...a....

(Rendra, 1994)

Dalam puisi tersebut, W.S. Rendra menegaskan lagi bahwa wacana pembangunan dan stabilitas nasional hanya enak di dengar tetapi faktanya menyengsarakan rakyat. Penggunaan simbol "Kecoa" merupakan sindiran bahwa pembangunan yang dilaksanakan oleh pemerintah Orde Baru itu menjijikkan, busuk, penuh dengan perilaku tiranis, dehumanis, dan imperialis.

Selanjutnya, W.S Rendra menunjukkan inkonsistensi pelaksanaan pembangunan Orde Baru dengan diskursus "Trilogi Pembangunan" yang dijadikan sebagai payung hukum pembangunan. Kritik itu disampaikan dengan menunjukkan fakta secara simbolik bahwa pembangunan yang dilaksanakan sarat dengan kepentingan elit dan makin marak praktik monopoli dan konglomerasi oleh keluarga elit politik yang menguasai hajat hidup rakyat. Interogasi dalam bentuk sindiran disampaikan dalam puisi Mastodon dengan simbol "Gajah dan Mastodon" sebagai berikut.
Gajah-gajah bisa menjelma menjadi mastodon-mastodon. Mereka masuk ke laut dan menghabiskan semua ikan, ...melahap semen dan kayu lapis, tiang- tiang listrik, filem-filem import, minyak kasar, cengkih, kopi, dan bawang putih. mereka menyerbu kota, menghabiskan semua beras dan jagung, anak-anak kecil., makan gedung, jalan, dan jembatan.
Mereka menghancurkan sekolah, gereja, masjid, dan pasar-pasar tradisional. Mereka akan selalu membengkak selalu lapar..(Rendra, 1973; 1980)

Simbol "Gajah dan Mastodon" merupakan simbol elit, kroni, dan keluarganya. Tidak hanya para elit yang rakus menguasai kekayaan negara, tetapi juga anak cucunya. Mereka makin lama makin rakus, makin sewenang-wenang merampas hak rakyat "Mereka akan selalu membengkak selalu lapar". Dalam kutipan tersebut, Presiden Soeharto dalam menjalankan sistem pemerintahan sentralistik menggunakan konsep "man is right", namun menerapkan kesewenangwenangan dalam menjalankan sistem pemerintahan yang sentralistik dengan alat militer. Keinginannya yang kuat untuk menjadi orang nomor satu dalam segalanya, menjadikan Ia juga tidak bisa Ambeg Paramarta Hasta Brata. Dengan sistem pemerintahan sentralistik seperti raja Jawa, anak-anak, kerabat, teman dekatnya diperlakukan bak pangeran dan diberikan fasilitas istimewa. Mereka menjadi bebas dan mudah untuk menguasai bisnis dan perekonomian negara yang menjadi hajat hidup rakyat dengan cara monopoli dan konglomerasi.

Berdasarkan analisis data di atas dapat diketahui bahwa interogasi W.S. Rendra terhadap pembangunan yang dilaksanakan oleh Orde Baru bersama kapitalis asing dan hutang luar negeri tidak memiliki visi yang jelas. Perencanaan pembangunan industri tambang dan ekonomi makro tidak didasarkan pada kajian potensi sumberdaya manusia dan fakta 
sejarah, tetapi atas arahan dan kontrol IMF dan World Bank. Pembangunan yang dilaksanakan dengan mendatangkan modal raksasa dan hutang luar negeri ternyata memiliki maksud yang tidak etik yaitu penumpukan ekonomi para elit beserta kroni dan keluarganya. Pembangunan yang berpayung UUPMA tahun 1967 dan diskursus pembangunan dan stabilitas pembangunan, pemerintah Orde Baru berhasil memasukkan neoimperialisme dengan sangat masif. Sebagai pemimpin dengan kultur Jawa, Presiden Soeharto tidak mampu Ambeg Paramarta Hasta Brata (tidak besikap adil, tidak menyejahterakan dan tidak memberikan kesejukan dan ketenteraman hasil pembangunan kepada rakyatnya. Beliau juga tidak mengemban amanat Kultur Jawa memayu hayuning braya (tidak berusaha menyelamatkan masyarakat), memayu hayuning bangsa (tidak berusaha menyelamatkan bangsa), dan memayu hayuning bawana (tidak berusaha menyelamatkan ibu pertiwi) (Hariwijaya, 2014).

\section{SIMPULAN}

Berdasarkan pembahasan kedua topik di atas dapat disimpulkan beberapa sebagai berikut. Pertama, payung hukum pembangunan industri tambang dan ekonomi makro yang dibuat oleh pemerintah Orde Baru bersama kapitalis asing, berupa UUPMATahun 1967 dan Penggunaan diskursus Trilogi Pembangunan telah memuluskan secara masif masuknya neoimperialis yang menguras kekayaan bumi pertiwi. Penggunaan diskursus Trilogi Pembangunan juga menumbuhkembangkan budaya gratifikasi, manipulasi, korupsi, dan konspirasi. Apabila strategi pembangunan Orde Baru dilanjutkan saat ini, maka society 5.0 mustahil dapat diimplementasikan di Indonesia, karena budaya manipulasi data sudah mengakar kuat, sementara akar dari sociaty 5.7 adalah data yang akurat.

Kedua, akibat dari payung hukum tersebut pembangunan industri tambang dilaksanakan oleh pemodal asing dalam bentuk kontrak karya, sangat merugikan negara. Pembangunan ekonomi makro hanya menguntungkan pemilik modal dan negara donor, sementara ekonomi rakyat kecil dan menengah makin tergencet dan terpinggirkan. Akibat dari wacana Stabilitas Nasional, menimbulkan budaya dehumanisasi berupa pengusiran, penindasan, penangkapan, pemiskinan, dan pembunuhan rakyat yang dianggap "Menghalangi" jalannya pembangunan (mempertahankan haknya). Akibat hutang luar negeri yang konspiratif, pembangunan Indonesia tidak berdaulat dan makin memiskinkan rakyat. Rakyat tidak menjadi pelaku pembangunan melainkan sebagai penonton dan budak pembangunan.

Disarankan kepada para pemangku pemerintah, baik legislatif maupun eksekutif belajar dari sejarah bahwa pembuatan payung hukum pembangunan sebaiknya mencerminkan cita-cita proklamasi, yakni lebih mengutamakan kedaulatan negara, kemandirian, kemakmuran, dan keadilan sosial. Untuk mengikis budaya korupsi, manipulasi, konspirasi, dan gratifikasi sebagiknya pembangunan dilaksanakan secara transparan. Pembangunan yang berdaulat adalah pembangunan yang sudah menyiapkan SDM sesuai dengan kebutuhan dan kekinian. Agar pembangunan humanis, maka konsep society 5.0 diterapkan dalam rancangan undang-undang.

\section{DAFTAR PUSTAKA}

Anderson, B. dan McVey, R. (2015). Di bawah Tiga Bendera; Anarkisme Global dan Imajinasi Antikolonial, Serpong: Marjin Kiri.

Aritonang, D. (1999). Runtuhnya Rezim Daripada Soeharto: Rekaman Perjuangan Mahasiswa Indonesia 1998. Bandung: Pustaka Hidayah.

Chaniago, A. (2001). Gagalnya Pembangunan: Kajian Ekonomi Politik terhadap Akar Krisis Indonesia. Jakarta: Pustaka LP3ES Indonesia.

Claessen, H.J.M. dan Sukadiyo, R.G. (1987). Antropologi Politik. Jakarta: Erlangga

Djarot, E, dkk. (2006). Siapa Sebenarnya Soeharto. Fakta dan Kesaksian para Pelaku Sejarah G-30-S. Jakarta: Media Kita.

Fakih, M. (2001). Sesat Pikir Teori Pembangunan dan Gobalisasi. Yogyakarta: Insist Press.

Interogasi W.S. Rendra terhadap Pembangunan Industri ... (Umi Salamah dan Rokhyanto) 
Foucault, M. (2011). Pengetahuan dan Metode, Karya-Karya Penting Foucault, Yogyakarta : Jalasutra.

Foucault, M. (2002). Wacana Kuasal Pengetahuan. Diterjemahkan oleh Yudi Santoso. Yogyakarta: Bentang Budaya.

Gramsci, A. (1986). Selections From Prison Notebooks . Eds. by Quintin Hoare and Geoffrey N.Smith. London: Lawrence and Wishart.

Hariwijaya, M. (2014). Filsafat Jawa Ajaran Luhur Warisan Leluhur. Yogyakarta: Gelombang Pasang.

Lake, A. J. (1973). Rendra, Penyair, dan Imajinasinya. Ende: Nusa Indah.

Pilger, J. (2002). The New Rules of the World, Verso, London.

Rendra, W.S. (1973). Mastodon dan Burung Kondor. Jakarta: Bank Naskah DKJ

Rendra, W.S. (1975). Perjuangan Suku Naga. Jakarta: Bank Naskah Dewan Kesenian Jakarta.

Rendra. W.S. (1983). Potret Pembangunan dalam Puisi. Jakarta: Pustaka Jaya

Rendra, W.S. (1995). Pidato Kebudayaan, Instropeksi Bangsa, di Taman Ismail Marzuki.

Rendra, W.S. (1997). Pidato Kebudayaan berjudul "Megatruh" disampaikan oleh W.S. Rendra diambil dari Harian Bernas, Edisi Senin, 17 November 1997.

Rendra, W.S. (1998). Puisi Kecoa Pembangunan dibawakan pada konser Kantata Takwa di Senayan, Jakarta, 6 Juli 1998

Rendra, W.S. (2004). Transkripsi Rekaman Video Dialog tentang Kebudayaan pada Acara Impact Di QTV Yang Dipandu oleh Pieter Gonta Video 1-6.

Rendra, W.S. (2008). Megatruh Kambuh: Teks Pidato Kebudayaan, Penerimaan Gelar Doktor Honoris Causa oleh Universitas Gajah Mada. Yogyakarta: Senat UGM.

Rendra, W.S. (2009). Saksi Ahli Kebudayaan Dari Pemerintah. Risalah Sidang Perkara Nomor 6/PUU-VII/2009
Perihal Pengujian Undang-Undang Republik Indonesia Nomor 32 Tahun 2002 Tentang Penyiaran terhadap Undang-Undang Dasar Negara Republik Indonesia Tahun 1945,

Smith, T. (1985). Requiem or New Agenda for Third World Studies. World Politics. Vol. 37, No. 4.

Soemanto, B. (2003). Rendra: Karya dan Dunianya. Jakarta: Grasindo.

Toussaint, E. (2015). Presiden Komisi Penghapusan Utang Negara Dunia Ketiga (CADTM), 5 November 2015: The Word Bank and the IMF in Indonesia.

Wood, M. (2013). Sejarah Resmi Indonesia Modern: Versi Orde Baru dan Para Penantangnya. Epilog oleh Dr. Asvi Warman Adam (LIPI). Yogyakarta Ombak Utama.

Kwik Kian Gie. (2011). Pak Harto Salah Memilih Tim Ekonomi dan Pengambilan Kebijakannya. http:// kwikkiangie.com/v1/2011/03/pakharto-salah-pilih-tim-ekonomi-dankebijakannya-artikel-2/.

Pichard, M. (2006). Pariwisata Budaya dan Budaya Pariwisata; Spillane, James J. Ekonomi Pariwisata: Sejarah dan Prospeknya; Hasyim, Muhammad.Krisis Masa Kinidan Orde Baru; http://dekanirmala. blogspot. co.id/2013/04/ perkembanganpariwisata-di-indonesia.html

Pilger, J. (2011).The New Rulers Of The World - YouTube: https://www.youtube. com/watch? $v=1$ wW1qJoWYPg

Rendra, W.S. (2004). Video WS Rendra saksi Ahli MK. https://www.youtube. com/ watch? $\mathrm{v}=\mathrm{Ufo} 4 \mathrm{NgcA} 6 \mathrm{WY}$

Rendra, W.S. (2004). Video 1--6 Dialog Kebudayaan Program Impact di $Q$ Channel yang dipandu oleh Peter Ghonta. https://www.youtube.com/ watch? $=$ cr V2z2EPL6M 